\title{
Effectiveness of Human Resource Practices Among Printing Press Organizations in Sivakasi
}

\begin{abstract}
Kasi Raman $\mathbf{R}^{1}$, Manikandan $\mathbf{N}^{2}$
${ }^{1}$ Author, Professor and Head, Department of MBA and Training and Placements, P.S.R. Engineering College, Sivakasi,

${ }^{2}$ Co-author, Associate Professor, Department of Management Studies, P.S.R. Engineering College, Sivakasi,

Abstract

The research was entitled as "Effectiveness of Human Resource Practices among Printing Press

Organizations in Sivakasi", reveals the importance of existing human resource practices followed in the organizations. The study analyses the various areas of human resource management in the organization such as recruitment and selection, training and development, performance appraisal, compensation policy and remuneration, motivation and welfare measures, and Industrial relations. The study examines the application of Human resource practices within the areas of the organization. The study confronts the functions and role of HR executives in focus with recruitment and selection of manpower and also training \& development for the workforce. The research methodology was carried out in a survey crosssectional applied to 350 respondents. Result of research showed that negative correlation between the performance appraisal and compensation. The findings revealed that the Human resource practices are the most important indicators in determining the growth of Printing Press organizations in Sivakasi.
\end{abstract}

Keywords: Human Resource practices, Performance appraisal, welfare measures

\section{Introduction}

\section{Introduction about the Study}

Human resource is the most important resource in the organization which is essential to combine all other resources in an effective manner for the productivity of an organization (Chib, 2012) ${ }^{1}$. Since the human resources are not similar with other resources and these resources are expecting some recognition and dignity in the workplace, they should be properly treated and motivated (Balachandar et al., 2013) ${ }^{2}$. In today's economic instability, organization started to look into people as an asset so that organization can utilize their skills, knowledge and abilities to sustain the competitiveness in the industry. This is because employees who are engaged in their work and committed to their organizations give crucial competitive advantages including higher productivity and lower employee turnover (Robert, 2006) ${ }^{3}$.

Employees in manufacturing sector are facing bigger challenges nowadays, as the expectations by their employers are increasing. The manufacturing industry in the whole world is facing a rapid transformation. The introduction of new techniques, technologies, systems, procedures and standards are everyday occurrences; thus, there is a tremendous need for the employees to keep up with the evolving trend. In order

\footnotetext{
${ }^{1}$ Chib, S., (2012), Analytical study on employee satisfaction, MIDC, Butibon, Nagpur", International Journal of Research in Computer Application and Management, 2(1), pp.96-103.

${ }^{2}$ Balachandar, G., Panchanatham, N. and Subramanian, K., (2013), "Quality of Work life the Power of Insurance Company: Impact of Personal factors on the QWL of the officers", Management and Marketing Journal, 9(1), pp.123-133.

${ }^{3}$ Robert, M., 2006. Stress in the Work Place. (1st Edition). New Jersy. Pearson Publishers.
} 
to maintain a high output and efficiency of the employees, organizations are now very much concerned with the psychological state of their workers.

\section{Definition}

According to Khatri, people are one of the most important factors providing flexibility and adaptability to organizations. Rundle, argues that one needs to bear in mind that people (managers), not the firm, are the adaptive mechanism in determining how the firm will respond to the competitive environment.

Human resources may be defined as the total knowledge, skills, creative abilities, talents and aptitudes of an organization's workforce, as well as the values, attitudes, approaches and beliefs of the individuals involved in the affairs of the organization. It is the sum total or aggregate of inherent abilities, acquired knowledge and skills represented by the talents and aptitudes of the persons employed in the organization.

\section{Human Resource Practices}

Human resources are multi - dimensional in nature. From the national point of view, human resources may be defined as the knowledge, skills, creative abilities, talents and aptitudes obtained in the population; whereas from the view point of the individual enterprise, they represent the total of the inherent abilities, acquired knowledge and skills as exemplified in the talents and aptitudes of its employees.

Human resource management practices are topics that have been covered by a large number of researchers worldwide for decades to analyze the relationship between HR practices on employee retention (Qureshi, $1994)^{4}$.

On the other hand, if human resource management practices are not implemented properly in an organization there are several negative impacts. An organization with proper human resource management practices enjoys the firm's sustainable growth that will maximize the economic opportunities in order to

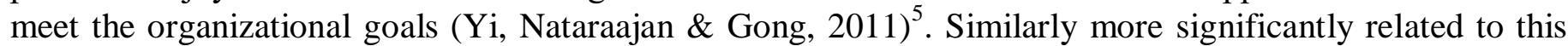
research will retain employees and improve their performance (Singh \& Jain, 2014) ${ }^{6}$.

Human resources are the source of achieving competitive advantage because of its capability to convert the other resources (money, machine, methods and material) in to output (product/service).

\section{Purpose of Research}

Human Resource Management today has to play a more strategic and business partnership role. Every organization controls a portfolio of powerful tools, through which it can influence or seek to influence employee attitude and behavior. A key focus of the human resource management is highlighted in the role of staffing, performance management, training and development, and compensation that plays indifferent types of business strategies. With the acquisition and preparation of human resources, including planning, recruitment, selection, and training can affect the whole organizational performance. Human Resource Practices can satisfy an employee's need to feel comfortable in the work-relationship with the organization and can make him/her feel comfortable in the work environment. Through the HR Practices the organizations could convey to the employee that, every employee is vital to the organization and the employees' commitment is solicited and valued.

The main need of this study is to interrogate the employees' opinion towards HRM practices in Printing Press organizations in Sivakasi. The research is mainly focused with the view of employees thought towards various areas of human resource management practices in which human resource executives play their vital

\footnotetext{
${ }^{4}$ Qureshi, Z. I., 1994. Impact of Management Practices on Employee Effectiveness in South Asia. Centre for Management and Economic Research, pp-4-27.

${ }^{5}$ Ghazali, D. H., Nasyuki. N. M. \& Xiao Yi, O., 2008. Human Resource practices and employee's intention to stay in the Kuala lumpur Hotel Industry, pp. 88-118.

${ }^{6}$ Singh, D. \& Jain, N., 2014. To study the effectiveness of HRM practices in Textile Industries, In Madhya Pradesh. India. Global Journal of Human Resource Management, September, 2(3), pp-59-72.
} 
roles and improving the better working conditions in the organization. Thus the research would be an evidential soundness for the organization to adapt better organizational climate in the near future.

\section{Scope of the Study}

A research entitled, "Effectiveness of Human Resource Practices among Printing Press Organizations in Sivakasi", reveals the importance of existing human resource practices followed in the organization. The research initializes with analyzing the demographic profiling of employees in the organization. The study analyses the various areas of human resource management in the organization such as recruitment and selection, training and development, performance appraisal, compensation policy and remuneration, motivation and welfare measures, and Industrial relations. The study examines the application of Human resource practices within the areas of the organization. The study confronts the functions and role of HR executives in focus with recruitment and selection of manpower and also training \& development for the workforce.

The study also determines the employees' expectation towards the existing appraisal system and compensation in the organization. The study also highlights the importance of human resource practices based on employees' satisfaction in the organization.

\section{Review of Literature}

Ong Choon Hee et.al. (2019), This study is to examine the relationship between Human Resource Management (HRM) practices and job performance in the courier service industry. Data was collected through questionnaire from 100 employees of a courier service company in Johor, Malaysia. The results of the multiple regression analysis showed that employment security and training and development were significantly related to job performance. Compensation and benefits and performance management were found to be not significant in predicting job performance. In relation to these findings, human resource department shall put effort to create a climate of confidence on the company's work force so that employees will feel more secured and design suitable training programs that lead to the acquisition of new knowledge and skills for personal growth and enhancing job performance.

Kasi Raman and Geetha (2019), The purpose of this research is to explore the experiences of employees with respect to the quality of their work life and there was no previous research has been conducted on quality of work life in SOS International Mechanical Equipment LLC, Abu Dhabi, UAE. This research is needed to know about the employees' quality of work life in SOS International Mechanical Equipment LLC, Abu Dhabi, UAE. The research also helps the organisation to identify the most related factors of quality of work life like adequate and fair compensation, working conditions, social integration etc.

Corine et. al. (2019), In the strategic human resource (HR) management literature, over the past three decades, a shared consensus has developed that the focus should be on HR systems rather than individual HR practices because the effects of HR practices are likely to depend on the other practices within the system. Offering actionable suggestions on how to advance HR systems research towards conceptual clarity and construct refinement, focusing both on how to conceptualize, measure, and combine practices in systems and on studying such systems at different levels of analysis.

Adel Ali Yassin. (2018), The main objective of this study is to investigate the influence of Human Resources Management (HRM) practices (employee communications, employee development and rewards and recognitions) on employee engagement. Employee engagement has emerged as one of the most important topics in the sphere of human resource management. The aim of this paper is to examine and gain better understanding of the drivers that influence employee engagement in a printing company. Employee communication, employee development, rewards, and recognitions were selected as independent variables.

Vaishali \& Jyotsana. (2018), Moreover, the organizations have understood the requirement of introducing innovative practices, products and processes. The main objective of this review based study is to identify the HR practices and review their role in organizational innovation. This review explores the theoretical and 
empirical findings from more than 30 research papers and articles, which discusses the role of HRM practices in organizational innovation. This review uses publications from the relevant journal articles, edited works, and other research materials to achieve the objective of the study. Based on the findings, it is identified that instead of focusing on a single HRM practice, there is a need to analyze a variety of HRM practices and effects that has a significant influence on organizational innovation.

Lina Hamdan. (2018), The study was steered in order to identify the impact of high performance human resources practices on job performance; in-role job performance and innovative job performance and to examine the mediating role of affective commitment on the effect of high performance human resources practices on job performance; in-role job performance and innovative job performance. In consonance with the results, affective commitment significantly and positively mediated the impact of high performance human resources practices on job performance; in-role job performance and innovative job performance. Full mediation of effective commitment was found on the effect of high performance human resources practices on in-role job performance and a partial mediation of affective commitment on the effect of high performance human resources practices on innovative job performance.

Kasi Raman and Geetha (2017), concluded that the quality of work life factors namely adequate and fair compensation, safe and healthy working environment, opportunities for growth, security, social relevance in work life, social integration and cohesiveness have a significant positive impact on job satisfaction among the employees. There is no significant relationship exists between years of experience and improvement of productivity \& overall quality of working life of Tamil Nadu State Transport Corporation.

Kasi Raman and Geetha (2017), helps to determine the most inducing stressors among employees' which lowers employees' performance in the organization. The external factor is beyond the control of organization. The findings showed that occupational stress does not have a direct impact on intention to leave and absenteeism. First organization need to increase job satisfaction by reducing occupational stress. By reducing stress, organizations preserve reducing the intention to leave and absenteeism.

Kasi Raman and Geetha (2017), The main need of this research is to analyze the workers' participation in management in order to ensure high performance and commitment to the organization's success. The research confronts the importance of workers' participation in order to capable of taking fruitful decisions regarding policy making, working conditions, productivity, manufacturing supervision and administration. The benefit of workers' involvement and commitment in management provides the opportunity to voice their opinions, which can lead to better human resource practices in the organization.

Mariyam Imna \& Zubair Hassan. (2015), study found that three human resource practices such as career development, reward and recognition, and health and safety have a positive and significant impact on employee retention. This research did not find any significant influence of training and development nor performance appraisal on employee retention. However, when training and development is linked with career development, there is a positive and significant influence on employee retention. Also when performance appraisal is linked with reward and compensation there is a positive and significant influence on employee retention. Though this study included only 14 retail organisations, future studies may include larger sample by conducting the research on more organisations including tourist resorts, particular only tourism industry. The future studies may compare differences based on socio-demographic profile and might examine the similarities and difference of HR practices in different sectors in Maldives.

Cheng Ling Tan et. al. (2011), Organizational innovation has been viewed as an essential weapon for organizations to compete in this competitive business environment. Particularly, Malaysia manufacturing firms strive to transform their business model from labor-intensive to knowledge-intensive, which aim to immerse themselves in higher value added activities such as, developing new products, processes, and services, to continual sustain the competitiveness within the rivalries. One of the ways to heighten the organizational innovation is through effective human resource management (HRM) practices and effective knowledge management. This study examined the direct relationships between HRM practices (performance 
appraisal, career management, training, reward system, and recruitment) and organizational innovation (product innovation, process innovation, and administrative innovation). Additionally, this study also demonstrates that training and performance appraisal, are positively related to knowledge management effectiveness. Knowledge management effectiveness fully mediates the relationship between training and process innovation, training and administrative innovation, and performance appraisal and administrative innovation.

Abang Azlan Mohamad, May-Chiun Lo \& Maw King La. (2009), It has become clear that firm performance has important implications for employees and organizations as confirmed by past researchers. This study examines human resource practices and the impact of incentives on manufacturing companies in the Malaysia context. Three types of human resource practices namely, performance appraisal, training, and information technology have been chosen as the focus of this research with the presence of incentives as moderator on organizational performance. This is imperative in order to ensure the successful management of employees and also to improve productivity and achievements of an organization.

\section{Objectives of the Study}

To study the effectiveness of Human Resource Practices among Printing Press organizations in Sivakasi.

* To identify the demographic profiling of employees in the organization.

* To trace out and review the existing human resource practices followed in the organization.

* To analyze the employees' satisfaction and expectations towards human resource practices among Printing Press organizations, Sivakasi.

\section{Research Methodology \\ Introduction}

Research is an academic activity and as such the term should be used in a technical sense. According to Clifford Woody, Research comprises defining and redefining problems, formulating hypothesis or suggested solutions; collecting, organizing and evaluating data; making deductions and reaching conclusions; and at last carefully testing the conclusions to determine whether they fit the formulating hypothesis.

\section{Research Design}

A research design is the arrangement of conditions for collection and analysis of data in a manner that aims to combine relevance to the research purpose with economy in procedure."

\section{Descriptive Research}

Descriptive research includes survey and fact-finding enquiries of different kinds. The major purpose of descriptive research is description of the state of affairs as it exists at present. The main characteristic of this method is that the researcher has no control over the variable; the researcher can only report what has happened or what is happening.

\section{Sampling Design}

A sampling design is a definite plan for obtaining a sample from a given population. It refers to the techniques or the procedure the researcher would adopt in selecting item for the sample.

\section{Sampling Method}

Probability sampling: Probability sampling form a finite population refers to that method of sample selection which gives each possible sample combination an equal probability of being picked up and each item in the entire population to have an equal chance of being included in the sample.

\section{Sampling Technique}

Simple Random Sampling: In some instance, every element in the population has a known and equal chance of being selected as a subject. 


\section{Sampling Unit}

The sampling unit of this study is Permanent Employees in Production unit of Printing press organizations in Sivakasi.

\section{Sample Size}

The sample size of the study is 350 .

\section{Sources of Data}

\section{Primary Data -}

The primary data are those which are collected afresh and for the first time, thus happen to be original in character.

\section{Secondary Data -}

The secondary data are those which have already been collected by someone else and which have already been passed through the statistical process.

\section{Data Collection Techniques}

In this study structured questionnaire are used for data collection. The questionnaire has been constructed in view of objectives of the study.

\section{Statistical Tool for Analysis}

The following tools used for analysis:

\section{Uni-Variate Percentage Analysis -}

Univariate Percentage Analysis refers to a specified kind which is used in making comparison between two or more series of data. Percentages are based on descriptive relationship. It compares the relative items. Since the percentage reduces everything to a common base and thereby allow meaning comparison.

$$
\text { Percentage Analysis }=\frac{\text { No.of Respondents }}{\text { Total No.of Respondents }} * 100
$$

\section{Weighted Average Analysis -}

Weighted average is referred to as weighted arithmetic mean or weighted arithmetic average and is defined for a set of values and non-negative associated weights as the sum of all values times their associated weights divided by the sum of the weights. A weighted average tends towards a given sample mean in proportion to the sample's size relative to the size of other samples being compared.

\section{$>$ Weighted Average Mean Analysis}

$>$ Weighted Average Rank Analysis

Weighted Average Analysis $=\frac{\sum_{i=1}^{n} \text { Value } * \text { Weightage }}{\text { Total No.of. Respondents }}$

Weighted Average Mean $=\frac{\text { Weighted Average Value }}{\text { Total No. of } \cdot \text { Attributes }}$

\section{Correlation Analysis -}

Correlation analysis studies the joint variation of two or more variables for determining the amount of correlation between two or more variables. It is a mathematical tool or technique that can be used to determine the relationship between the variables

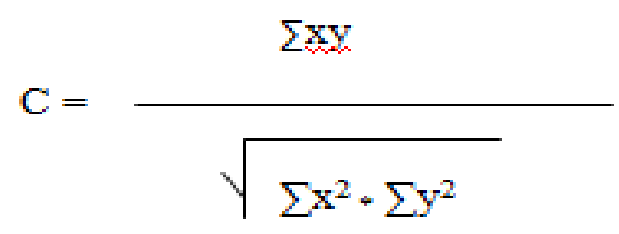




\section{Research Hypothesis}

There is no significant relationship between the performance appraisal and compensation in the Organization.

\section{Data Analysis and Discussion}

Table 1.1: Demographic Profile of Respondents

\begin{tabular}{|c|c|c|c|}
\hline \multicolumn{2}{|r|}{ Particulars } & No. of Respondents & Percentage $(\%)$ \\
\hline \multirow{2}{*}{ Gender } & Male & 275 & 79 \\
\hline & Female & 75 & 21 \\
\hline \multirow{2}{*}{$\begin{array}{c}\text { Marital } \\
\text { Status }\end{array}$} & Single/Unmarried & 53 & 15 \\
\hline & Married & 297 & 85 \\
\hline \multirow{5}{*}{ Age Group } & $18-25$ Years & 48 & 14 \\
\hline & $26-30$ Years & 65 & 18 \\
\hline & $31-35$ Years & 108 & 31 \\
\hline & $36-40$ Years & 62 & 18 \\
\hline & Above 40 years & 67 & 19 \\
\hline \multirow{4}{*}{$\begin{array}{c}\text { Education } \\
\text { Qualification }\end{array}$} & Up to school level & 182 & 52 \\
\hline & Under-graduate & 68 & 19 \\
\hline & Post-graduate & 16 & 5 \\
\hline & Diploma/ITI & 84 & 24 \\
\hline \multirow{5}{*}{$\begin{array}{l}\text { Monthly } \\
\text { Income } \\
\text { (in Rs.) }\end{array}$} & ₹ 8,000 - ₹ 15,000 & 176 & 50 \\
\hline & $₹ 15,000$ - ₹ 20,000 & 56 & 16 \\
\hline & $₹ 20,000$ - ₹ 25,000 & 48 & 14 \\
\hline & \begin{tabular}{|l|l|}
$₹ 25,000-₹ 30,000$ \\
\end{tabular} & 38 & 11 \\
\hline & Above ₹ 30,000 & 32 & 9 \\
\hline \multirow{6}{*}{$\begin{array}{c}\text { Years of } \\
\text { Work } \\
\text { Experience }\end{array}$} & Below 3 years & 158 & 45 \\
\hline & $3-5$ years & 64 & 19 \\
\hline & $5-7$ years & 34 & 10 \\
\hline & $7-9$ years & 40 & 11 \\
\hline & 9-11 years & 32 & 9 \\
\hline & Above 11 years & 22 & 6 \\
\hline \multirow{5}{*}{ Designation } & Production Manager & 5 & 2 \\
\hline & Supervisor & 20 & 6 \\
\hline & Electricians & 32 & 9 \\
\hline & Office Staff & 15 & 4 \\
\hline & Floor Employees & 278 & 79 \\
\hline \multirow{3}{*}{$\begin{array}{l}\text { Level of } \\
\text { Skills }\end{array}$} & Skilled & 92 & 26 \\
\hline & Semi-skilled & 258 & 74 \\
\hline & Unskilled & - & - \\
\hline
\end{tabular}

\section{Source: Primary Data}

Demographic Profile of respondents

* $79 \%$ of the respondents were male, who are employed in the organization.

* Majority of the respondents were married $(85 \%)$ who worked in the organization.

* Majority of the respondents were aged 30-35 years (31\%) followed by above 40 years (19\%), 25 30 years \& $35-40$ years $(18 \%)$, and $18-25$ years $(14 \%)$ 
Majority of the respondents were having up to school level education (52\%) who worked in the organization.

* Majority of the respondents were earning between Rs. $8000-15000$ (50\%) in the organization.

* Majority of the respondents were having below 3 years of experience (45\%) who worked in the organization.

Majority of the respondents were semi-skilled (74\%) who worked in the organization.

Table 1.2: Uni - variate Percentage Analysis

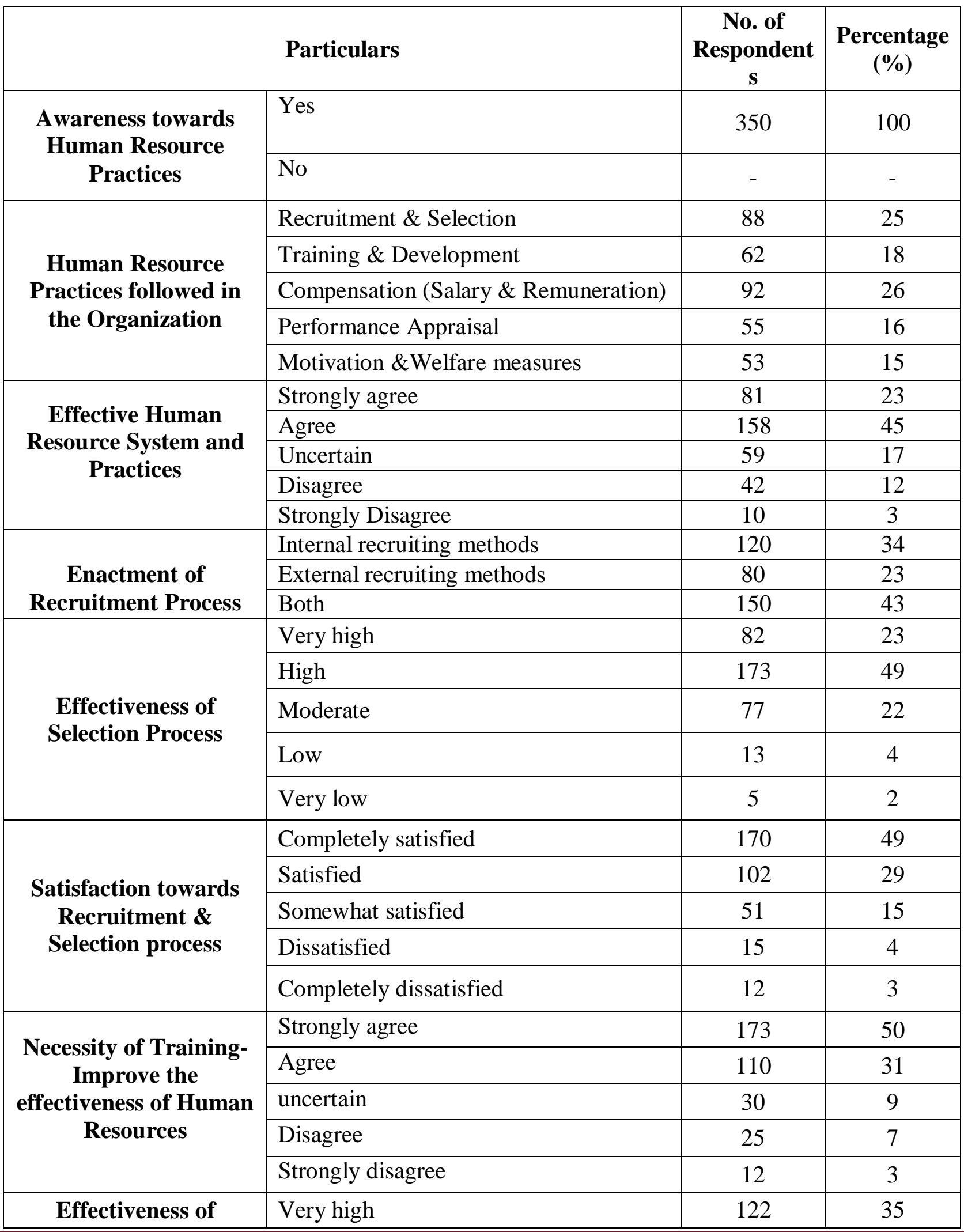




\begin{tabular}{|c|c|c|c|}
\hline \multirow[t]{4}{*}{ Training programs } & High & 98 & 28 \\
\hline & Moderate & 97 & 28 \\
\hline & Low & 18 & 5 \\
\hline & Very low & 15 & 4 \\
\hline \multirow{4}{*}{$\begin{array}{c}\text { Frequency of } \\
\text { Performance appraisal } \\
\text { in the Organization }\end{array}$} & Once a need arises & 128 & 37 \\
\hline & Once a six months & 92 & 26 \\
\hline & Once a year & 103 & 29 \\
\hline & Once a regular basis/frequently & 27 & 8 \\
\hline \multirow{5}{*}{$\begin{array}{c}\text { Kinds of } \\
\text { Reinforcement } \\
\text { provides Positive } \\
\text { Influences }\end{array}$} & Promotion & 86 & 31 \\
\hline & Salary Increment & 78 & 28 \\
\hline & Incentives & 65 & 23 \\
\hline & Bonus and rewards & 49 & 18 \\
\hline & Others & - & - \\
\hline \multirow{5}{*}{$\begin{array}{l}\text { Perception towards } \\
\text { Performance Appraisal } \\
\text { System in the } \\
\text { Organization }\end{array}$} & Excellent & 152 & 43 \\
\hline & Very Good & 93 & 27 \\
\hline & Good & 84 & 24 \\
\hline & Average & 13 & 4 \\
\hline & Fair & 8 & 2 \\
\hline \multirow{5}{*}{$\begin{array}{l}\text { Compensation Policy } \\
\text { in the Organization }\end{array}$} & Very good & 182 & 52 \\
\hline & Fairly good & 102 & 29 \\
\hline & Neither good nor bad & 38 & 11 \\
\hline & Not very good & 18 & 5 \\
\hline & Not good at all & 10 & 3 \\
\hline \multirow{5}{*}{$\begin{array}{l}\text { Motivation- Important } \\
\text { for Development the } \\
\text { Organization }\end{array}$} & Strongly agree & 128 & 36 \\
\hline & Agree & 146 & 42 \\
\hline & Uncertain & 52 & 15 \\
\hline & Disagree & 14 & 4 \\
\hline & Strongly disagree & 10 & 3 \\
\hline \multirow{5}{*}{$\begin{array}{l}\text { Intra-Mural facilities } \\
\text { provided in the } \\
\text { Organization }\end{array}$} & Medical facilities & 88 & 25 \\
\hline & Provision of crèches \& canteens & 96 & 27 \\
\hline & Supply of drinking water & 81 & 23 \\
\hline & Compensation for accidents & 66 & 19 \\
\hline & $\begin{array}{l}\text { Improved conditions for working } \\
\text { environment }\end{array}$ & 19 & 6 \\
\hline \multirow{5}{*}{$\begin{array}{l}\text { Periodic reviews about } \\
\text { Welfare Measures }\end{array}$} & Strongly agree & 171 & 49 \\
\hline & Agree & 102 & 29 \\
\hline & Uncertain & 51 & 14 \\
\hline & Disagree & 16 & 5 \\
\hline & Strongly disagree & 10 & 3 \\
\hline \multirow{2}{*}{$\begin{array}{l}\text { Perception towards } \\
\text { HR Practices }\end{array}$} & Excellent & 102 & 29 \\
\hline & Very Good & 120 & 34 \\
\hline
\end{tabular}




\begin{tabular}{|c|c|c|c|}
\hline & Good & 96 & 27 \\
\hline & Average & 22 & 7 \\
\hline & Fair & 10 & 3 \\
\hline \multirow{5}{*}{$\begin{array}{c}\text { Overall Satisfaction } \\
\text { towards Human } \\
\text { Resource Practices }\end{array}$} & Highly satisfied & 106 & 30 \\
\hline & Satisfied & 140 & 40 \\
\hline & Neutrally satisfied & 66 & 19 \\
\hline & Dissatisfied & 28 & 8 \\
\hline & Highly dissatisfied & 10 & 3 \\
\hline
\end{tabular}

\section{Source: Primary Data}

Inference:

Based on the Uni - variate Percentage analysis, the researcher infers that

All of the respondents (100\%) are having awareness about Human Resource Practices followed by the organizations.

* Majority of the respondents (26\%) said that compensation as prior practice, is regularly followed by the organizations.

* Majority of the respondents (45\%) are agree that their organization have an effective Human Resource System and Practices.

* Majority of the respondents (43\%) said that the organization follows both internal and external recruitment sources.

* Majority of the respondents (49\%) are completely satisfied with recruitment \& selection process followed in the Organizations.

* Majority of the respondents (50\%) are strongly agree that the organization have an effective training, which improves the effectiveness of Human Resources.

* Majority of the respondents (35\%) are rated as very high towards the effectiveness of training program followed in the organizations.

* Majority of the respondents (37\%) said that frequency of performance appraisal is based on once a need arises in the organizations.

* Majority of the respondents (31\%) are having about positive influences through promotion offered in the organizations.

* Majority of the respondents (43\%) are perceived as excellent towards the performance appraisal system followed in the Organizations.

* Majority of the respondents (52\%) are perceived as very good towards compensation policy followed in the Organizations.

* Majority of the respondents (42\%) are agreed that the motivation is important among workforce for the Organizational Development.

* Majority of the respondents (27\%) said that, provision of crèches \& canteens among intra-mural facilities followed in the Organizations.

* Majority of the respondents (49\%) are strongly agrees that the organizations have periodic reviews about welfare measures by welfare officer. 
Majority of the respondents (34\%) are perceived as good towards Human Resource practices followed by the organizations.

* Majority of the respondents (40\%) are satisfied with the existing Human Resource Practices followed in Printing Press Organizations in Sivakasi.

Table 1.3: Weighted Average Analysis

1.3.1 - Weighted Average Rank

Respondents' Perception towards Financial Motivation

\begin{tabular}{|c|l|c|c|c|c|c|c|c|}
\hline S. No & \multicolumn{1}{|c|}{ Attributes } & $\mathbf{5}$ & $\mathbf{4}$ & $\mathbf{3}$ & $\mathbf{2}$ & $\mathbf{1}$ & Average & Rank \\
\hline 1 & Compensation & 85 & 116 & 64 & 73 & 12 & 3.54 & 5 \\
\hline 2 & Bonus & 90 & 133 & 65 & 58 & 4 & 3.99 & 1 \\
\hline 3 & Medical allowances & 80 & 128 & 105 & 30 & 7 & 3.70 & 3 \\
\hline 4 & Cash Incentives & 77 & 146 & 85 & 37 & 5 & 3.72 & 2 \\
\hline 5 & Insurance schemes & 96 & 120 & 69 & 58 & 7 & 3.69 & 4 \\
\hline
\end{tabular}

Source: Primary Data

Weightage:

$\begin{array}{ll}5-\text { Excellent } & 2-\text { Average } \\ 4-\text { Very Good } & 1-\text { Fair } \\ 3-\text { Good } & \end{array}$

Inference

TOTAL $=\sum$ VALUE * WEIGHTAGE

Weighted Average Analysis $=\frac{\sum_{i=1}^{n} \text { Value } * \text { Weightage }}{\text { Total No.of. Respondents }}$

WEIGHTED AVERAGE = weighted average value

Total number of attributes

$$
\begin{aligned}
& =\frac{3.54+3.99+3.70+3.72+3.69}{5} \\
& =\sim 3.74=4
\end{aligned}
$$

Based on Weighted average rank analysis,

* Most of the respondents are ranked bonus as first followed by cash incentives, medical allowances, insurance schemes and compensation among financial motivation and perceived as good, provided in the Organization.

1.3.2 - Weighted Average Rank

Respondents' Perception towards Non-Financial Motivation

\begin{tabular}{|c|l|c|c|c|c|c|c|c|}
\hline S. No & \multicolumn{1}{|c|}{ Attributes } & $\mathbf{5}$ & $\mathbf{4}$ & $\mathbf{3}$ & $\mathbf{2}$ & $\mathbf{1}$ & Average & Rank \\
\hline 1 & Recognition & 88 & 130 & 80 & 48 & 4 & 3.71 & 3 \\
\hline 2 & Job security & 76 & 138 & 95 & 37 & 4 & 3.7 & 4 \\
\hline 3 & Job promotions & 82 & 145 & 92 & 28 & 3 & 3.78 & 1 \\
\hline 4 & Career development & 86 & 142 & 88 & 27 & 7 & 3.78 & 1 \\
\hline
\end{tabular}

Source: Primary Data

Weightage:

$\begin{array}{ll}5-\text { Excellent } & 2-\text { Average } \\ 4-\text { Very Good } & 1-\text { Fair } \\ 3-\text { Good } & \end{array}$




\section{Inference}

TOTAL $=\sum$ VALUE $*$ WEIGHTAGE

Weighted Average Analysis $=\frac{\sum_{i=1}^{n} \text { Value } * \text { Weightage }}{\text { Total No.of. Respondents }}$

WEIGHTED AVERAGE = weighted average value

Total number of attributes

$$
\begin{aligned}
= & \frac{3.71+3.7+3.78+3.78}{4} \\
= & \sim 3.74=4
\end{aligned}
$$

Based on Weighted average rank analysis,

* Most of the respondents are ranked career development as first followed by job promotions, recognition and job security among non-financial motivation and perceived as good, provided in the Organization.

Table 1.4: Correlation Analysis

1.4.1 - Relationship between Performance appraisal and Compensation

Null Hypothesis (Ho): There is no significant relationship between the performance appraisal and compensation.

Alternative Hypothesis (Ha): There is significant relationship between the performance appraisal and compensation.

\begin{tabular}{|l|l|c|c|}
\hline \multicolumn{2}{|c|}{ Correlations } \\
\hline \multirow{5}{*}{ Performance } & \multicolumn{1}{|c|}{$\begin{array}{c}\text { Performance of the } \\
\text { respondents }\end{array}$} & $\begin{array}{c}\text { Compensation of } \\
\text { the respondents }\end{array}$ \\
\hline \multirow{5}{*}{ Compensation } & $\begin{array}{l}\text { Pearson } \\
\text { Correlation }\end{array}$ & 1 & -.004 \\
\cline { 2 - 4 } & Sig. (2-tailed) & -- & .937 \\
\cline { 2 - 4 } & $\mathrm{N}$ & 350 & 350 \\
\hline & $\begin{array}{l}\text { Pearson } \\
\text { Correlation }\end{array}$ & -.004 & 1 \\
\cline { 2 - 4 } & Sig. (2-tailed) & .937 & -- \\
\cline { 2 - 4 } & $\mathrm{N}$ & 350 & 350 \\
\hline
\end{tabular}

**. Correlation is significant at the 0.01 level (2- tailed)

Significant value $=0.937$

Critical Value $=0.05$

Significant Value is greater than the Critical Value. Therefore, alternative hypothesis is rejected.

\section{Inference:}

Based on Correlation analysis,

Negative correlation exists, there is no significant relationship between the performance appraisal and compensation in the Organization.

\section{Major Recommendations}

Most of the respondents are felt that the effectiveness of the selection process is low. Hence the organization shall consider in improving the selection process and henceforth the vital people resource would be enhanced and stands for organizational productivity. 
Most of the respondents are thought that the effectiveness of training program is low. Hence the organization shall improve the training practices by using visual ads, conference and lectures.

There is no significant relationship between the satisfaction of the respondents on the extent of implementation towards knowledge of trainers in the organization. Hence the organization might sort out the best class trainers to train the various modules stands for operational excellence.

> Human Resource reviews the performance management system. Employees should be valuable perception towards performance appraisal system in the organization. The introduction of goals setting and performance appraisal feedback giving are important areas to be practiced in all departments and the organization shall implement outcome based systems to enhance the evaluation process.

\section{Conclusion}

Human resource management practices is a topic that have been covered by a large number of researchers worldwide for decades to analyze the relationship between HR practices on employee retention. A large number of empirical studies verify a positive relationship between human resource management practices on organizational performance mainly in relation to employee retention. Looking at the most recent findings among the studies conducted on this context training and development, health and safety, reward and compensation, career development, supervisor support, recruitment, performance appraisal, work and family balance and wage are some of the key practices that influence employee retention.

The goal of the Best Practices project was to determine whether and to extent there were "best international HRM practices" that might serve as a common denominator across different cultures and nations and that might be related to organizational effectiveness. The intention was to examine empirically whether certain HRM practices varied across nations and in terms of their relationship with organizational effectiveness. 


\section{BOOK SOURCES}

1. Kothari C R, Research Methodology - Methods \& Techniques, New Age International Publishers, New Delhi, P. No. 1 to 56

2. Dessler, Human Resource Management, Pearson Education Limited, New Delhi, P.No.223 to 258

3. Aswathappa, K, Human resource management: Text and cases, Tata Mc Graw Hill Publishing Company Limited, New Delhi, P. No. 123 to 130

\section{JOURNAL SOURCES}

1. Abang et. al.., (2009), Human Resource Practices and Organizational Performance. Incentives as Moderator, Journal of Academic Research in Economics, 2(1), pp.229-244

2. Adel Ali Yassin. (2018), The Influence of Human Resource Management Practices on Employee Work Engagement, Foundations of Management, 10(1), pp. 251 - 256

3. Balachandar, G., Panchanatham, N. and Subramanian, K., (2013), "Quality of Work life the Power of Insurance Company: Impact of Personal factors on the QWL of the officers", Management and Marketing Journal, 9(1), pp.123-133.

4. Chib, S., (2012), Analytical study on employee satisfaction, MIDC, Butibon, Nagpur", International Journal of Research in Computer Application and Management, 2(1), pp. 96-103

5. Corine Boon, Deanne N. Den Hartog \& David Lepak (2019), A Systematic Review of Human Resource Management Systems and their measurement, Journal of Management, 45(6), pp. 2498 2537

6. Ghazali, D. H., Vasuki., N. M. \& Xiao Yi, O., 2008. Human Resource practices and employee's intention to stay in the Kuala lumpur Hotel Industry, pp. 88-118.

7. Kasi Raman R \& Geetha V., 2019. Impact of Quality of Work Life on Job Satisfaction among Expatriates in SOS International Mechanical Equipment LLC, Abu Dhabi - UAE, International Journal of Research and Analytical Reviews, 1(1), pp.141-147

8. Kasi Raman R \& Geetha V., 2017. Quality of Work Life among employees in Tamil Nadu State Transport Corporation with reference to Tuticorin division, Asian Academic Research Journal of Multidisciplinary (AARJMD), 4(11), pp.53-68

9. Kasi Raman R \& Geetha. V, 2017. An Analysis of Occupational Stress and Its Impact on Employees' Absenteeism among Spinning Mills, Rajapalayam, International Journal of Scientific Research and Management, 2017, 5(11), pp.7545-7559

10. Kasi Raman R \& Geetha. V, (2017). Workers' opinion towards Participation in Management among Spinning Mills in Rajapalayam, Zenith International Journal of Business Economics \& Management Research, 2017, 7(1), pp.31-50

11. Lina Hamdan Mahmoud Al-Abbadi (2018), The Impact of High Performance Human Resource Practices on In-Role and Innovative Job Performance: The Mediation role of Affective Commitment, Global Journal of Management and Business Research, 18(4), pp. 53-65

12. Mariyam, I \& Zubair Hassan., (2015), Influence of Human Resource Management practices on Employee Retention in Maldives Retail Industry, International Journal of Accounting and Business Management, 3(1), pp.50-80

13. Ong Choon Hee, et. al. (2019), The relationship between Human Resource Management Practices and Job Performance in the courier service Industry, International Journal of Academic Research in Business and Social Sciences, 9(3), pp. $63-79$

14. Qureshi, Z. I., 1994. Impact of Management Practices on Employee Effectiveness in South Asia. Centre for Management and Economic Research, pp. 4-27

15. Robert, M., 2006. Stress in the Work Place. (1st Edition). New Jersy. Pearson Publishers.

16. Singh, D. \& Jain, N., 2014. To study the effectiveness of HRM practices in Textile Industries, In Madhya Pradesh, India. Global Journal of Human Resource Management, 2(3), pp-59-72. 
17. Tan, C, L and Nasurdin, A, M. (2011), Human Resource Management Practices and Organizational Innovation: Assessing the Mediating Role of Knowledge Management Effectiveness, The Electronic Journal of Knowledge Management, 9(2), pp155-167.

18. Vaishali Sharma \& Jyotsana Sharma (2018), Organizational Innovation through HR Practices: A Review based analysis, International Journal of Enhanced Research in Management \& Computer Applications, 7(1), pp. 159 - 166. 